\title{
ANALISIS PRODUKSI PERIKANAN LAUT TERHADAP KESEJAHTERAAN MASYARAKAT KABUPATEN LAMONGAN
}

\author{
*(Abid Muhtarom \\ Fakultas Ekonomi \\ Universitas Islam Lamongan
}

\begin{abstract}
ABSTRAK
Sektor peruntukan dalam bidang kelautan sangatlah penting baik dalam bidang pemenuhan kebutuhan akan konsumsi dalam negeri dalam sektor maritim namun juga dapat juga digunakan sebagai pendapatan nasional yang digunakan untuk penigkatan pembangunan atau pun kegiatan pemerntah yang lain sehingga dapat mencipatakan kesejahteraan masyarakat.

Penelitan ini menggunakan penelitian eksplanatori, yaitu hasil yang diperoleh dalam penelitian ini diharapkan dapat memberikan penjelasan tentang bagaimana Analisis Produksi Perikanan Laut Terhadap Kesejahteraan Masyarakat Kabupaten Lamongan. Ditinjau dari sifat hubungan antara variabelnya, penelitian ini dirancang sebagai penelitian kausal dimana variabel yang satu dengan yang lain tidak sekedar dijelaskan hubungan korelasinya, lebih dari itu akan didiskripsikan dan dianalisis dengan menggunakan SPSS 23.

Partipasi masyarakat hanya sebatas sebagai tenaga kerja karena masyarakat tidak mempunyai modal yang besar,maka dari pada itu produksi perikanan laut sebagai variabel bebas terhadap kesejahteraan masyarakat Kabupaten Lamongan sebagai variabel terikat menjadikan pengaruh singnifikan namun negatif karena kontribusi yang diberkan masih sangat minim,sehingga dapat mempengaruhi kesejahteraan masyarakat.
\end{abstract}

Kata Kunci: Produksi perikanan laut dan kesejahteraan masyarakat.

\section{PENDAHULUAN}

merupakan Negara kepulauan sebagain besar wilayah Indonesia berupa lautan dan mata pencarihan sebagian besar masyarakatanya di bidang maritim dan agraris.

Sehingga pemerintah melaksana-kan banyak kebijakan tentang pemberdayaan potensi laut atau maritim. Adanya Negara maritim menyebabkan pemerintah daerah tidak hanya tutup mata untuk meningkatkan potensi yang ada. Mulai dari kebijakan Tol laut sampai dengan pengawasan sektor kelutan untuk menangulangi pencurian yang dilakukan oleh pihak lain.

Sektor peruntukan dalam bidang kelautan sangatlah penting baik dalam bidang pemenuhan kebutuhan akan konsumsi dalam negeri dalam sektor maritim namun juga dapat juga digunakan sebagai pendapatan nasional yang digunakan untuk penigkatan pembangunan ataupun kegiatan pemerntah yang lain sehingga dapat mencipatakan kesejahteraan masyarakat. 
Produksi Perikanan Sektor

Laut Tahun 2011-2015

mempunyai dampak yang baik bagi pemerintah kabupaten lamongan karena daerah Kabupaten Lamongan sebagian wilayah daerahnya berada di pesisir pantai bagaian utara pulau jawa (pantura) dari beberapa data yang didapat mulai tahun 20112015 dapat menjelaskan potensi pendapatan daerah akan produksi perikanan sektor lautan mulai tahun 2011 sampai dengan 2015 terus mengalami kenaikan pertahunya. Pada tahun 2011 sendiri pada sebesar Produksi perikanan sektor laut 68,302 Ton dengan pertumbuhan $1,02 \%$ dan terus naik dalam perolehanya pada tahun 2015 sebesar 72,346 Ton dengan pertumbuhan $1,10 \%$ (sember: Dinas Perikanan dan Kelautan Kab. Lamongan)

Kesejahteraan masyarakat kabupaten lamongan dapat juga menjadikan hal penentu dari Produksi Perikanan Sektor Laut menurut data Badan pusat statistik Jawa Timur tahun 2011-2015 dapat disimpukan bahwa mulai tahun 2011 besarnya IPM sebesar 66,21 satuan $1,24 \%$ dan pada tahun 2015 besarnya IPM sebesar 70.31 satuan $1,71 \%$, hal ini mengindikasikan bahwa terjadi penigkatan kesejahteraan masyarakat kabupaten Lamongan.

Permasalahan yang terjadi Produksi Perikanan Sektor Laut yang selama ini diharapkan menjadi sember daya penigkat pendapatan Asli daerah dapat menigkatkan kesejahteraan masyarakat kabupaten Lamongan pada umumnya, karena kita tahu bahwa tidak serta merta Produksi
Perikanan Sektor Laut naik akan menyebabkan kesejahteraan masyarakat Kabupaten Lamongan dapat terjadi.

\section{METODELOGI PENELITIAN}

Penelitan ini menggunakan penelitian eksplanatori, yaitu hasil yang diperoleh dalam penelitian ini diharapkan dapat memberikan penjelasan tentang bagaimana Analisis Produksi Perikanan Laut Terhadap Kesejahteraan Masyarakat Kabupaten Lamongan (Husaini, 2008:5).

Ditinjau dari sifat hubungan antara variabelnya, penelitian ini dirancang sebagai penelitian kausal dimana variabel yang satu dengan yang lain tidak sekedar dijelaskan hubungan korelasinya, lebih dari itu akan didiskripsikan dan dianalisis dengan menggunakan SPSS 23. Sesuai dengan rumusan masalah dan tujuan penelitian, secara hipotesis, diidentifikasikan variabel yang akan diteliti, yaitu : Produksi Perikanan Laut dan Kesejahteraan Masyarakat Kabupaten Lamongan.

\section{HASIL PENELITIAN}

\section{a. Produksi Perikanan Sektor Laut}

Dari hasil data penelitian tabel 3.1 dapat di jelaskan sebagai berikut pada tahun 2011 Produksi Perikanan Sektor Laut sebesar 68,302 Ton dimana pertumbuhannya $1,02 \%$. Pada tahun 2011 Produksi Perikanan Sektor Laut sebesar 69,216 Ton terjadi penigkatan dari tahun 2011 dan pertumbuhuhanya sebesar 
1,32\%. Pada tahun 2013 Produksi Perikanan Sektor Laut sebesar 70,150 Ton naik dari tahun 2012 pertumbuhanya naik sebesar $1,33 \%$ dan pada tahun 2014 Produksi Perikanan Sektor Laut sebesar 71,553 Ton pertumbuhan $1,96 \%$ naik dari tahun 2013. Sedangkan pada tahun 2015 Produksi Perikanan Sektor Laut sebesar 72,346 Ton pertumbuhanya turun $1,10 \%$. Hal ini yang menjadikan hal utama akan pentingnya produksi perikanan sektor laut. Diharapkan dapat menigkatkan sektor pendapatan daerah dan juga sebagai modal pemerintah untuk mengurangi pengangguran.

Tabel 1

Produksi Perikanan Sektor Laut Tahun 2011-2015

\begin{tabular}{|c|c|r|}
\hline \multirow{2}{*}{ Tahun } & \multicolumn{2}{|c|}{ Produksi Perikanan } \\
\cline { 2 - 3 } & Ton & Pertumbuhan \\
\hline 2011 & 68,302 & $1,02 \%$ \\
\hline 2012 & 69,216 & $1.32 \%$ \\
\hline 2013 & 70,150 & $1.33 \%$ \\
\hline 2014 & 71,553 & $1.96 \%$ \\
\hline 2015 & 72,346 & $1.10 \%$ \\
\hline
\end{tabular}

Sumber: Dinas Perikanan dan

Kelautan Kab. Lamongan

\section{b. Kesejahteraan Masyarakat Kabupaten Lamongan}

Tabel 2

IPM (indeks Pembangunan

Manusia ) Indikator Kesejahteraan masyarakat Kabupaten Lamongan

Tahun 2011-2015

\begin{tabular}{|c|r|r|}
\hline \multirow{2}{*}{ Tahun } & \multicolumn{2}{|c|}{ IPM } \\
\cline { 2 - 3 } & satuan & Pertumbuhan \\
\hline 2011 & 66,21 & $1,24 \%$ \\
\hline 2012 & 67,51 & $1.96 \%$ \\
\hline 2013 & 68,90 & $0,07 \%$ \\
\hline 2014 & 69,42 & $0.76 \%$ \\
\hline 2015 & 70.31 & $1,71 \%$ \\
\hline
\end{tabular}

Sumber: BPS Provinsi Jawa Timur

Hasil analisis data Kesejahteraan masyarakat Kabupaten Lamongan dapat di jelaskan pada tabel 3.2 sebagai berikut pada tahun 2011 pertumbuhan kesejahteraan masyarakat sebesar 1,24\% dengan satuan 66,21 terjadi kenaikan pada tahun 2012 sebesar 1,96\% dan satuan 67,51. Pada tahun 2013 Kesejahteraan masyarakat Kabupaten Lamongan naik dengan nilai satuan 68,90 namun pertumbuhanya tidak naik cukup tinggi sebesar 0,07. Pada tahun 2014 pertumbuhan Kesejahteraan masyarakat Kabupaten Lamongan 0,76\% naik dari tahun 2013 namun nilai satuan 69,42 juga megalami kenaikan pada tahun 2015 pertumbuhan Kesejahteraan masyarakat Kabupaten Lamongan 1,71 naik cukup besar dengan satuan 70,31 dari tahun 20132014. Kesejahteraan masyarakat diharapkan dapat menciptakan sesuatu yang positif bagi kehidupan bermasyarakat. 
c. Analisis data

Correlations

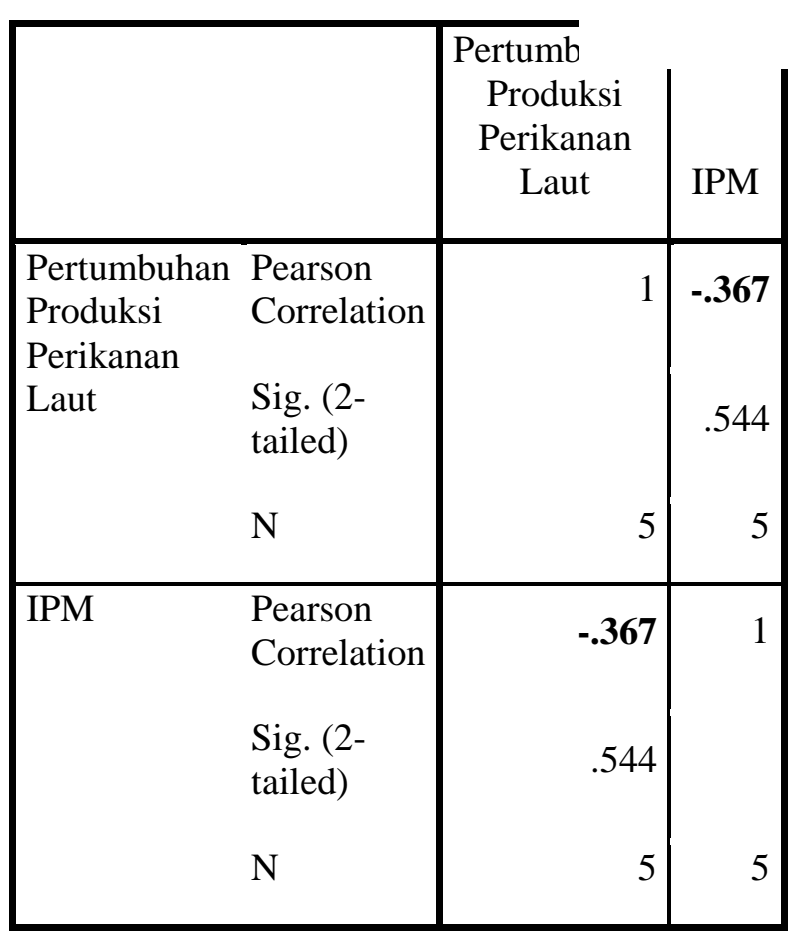

Pada analisis korelasi diatas antara Produksi perikanan laut dengan kesejahteraan masyarakat dengan sig.(2-tailed) sebesar 0,544 menghasilkan pearson's $\mathrm{r}$ angka 0,367 . Angka yang lebih kecil cari 0,05 maka Produksi perikanan laut dengan kesejahteraan masyarakat kabupaten Lamongan terdapat hubungan nyata dan signifikan negatif.

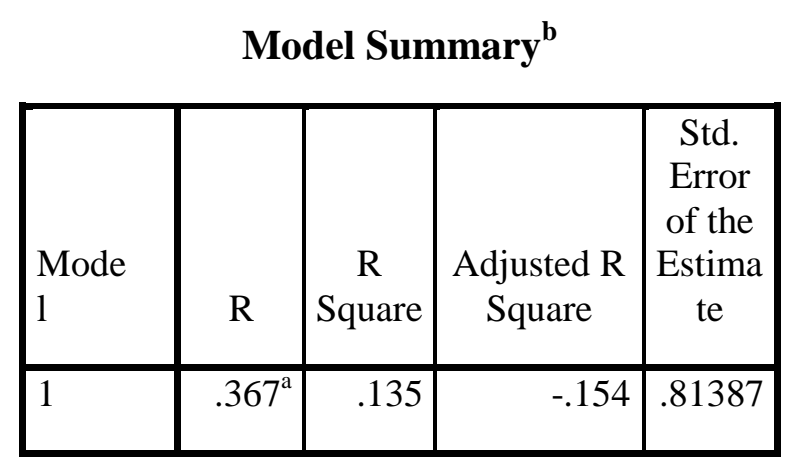

a. Predictors: (Constant), Pertumbuhan Produksi Perikanan Laut

b. Dependent Variable: IPM

Data tabel diatas menujukan nilai korelasi atau (R) hubungan adalah nilai sebesar 0,367 dan dijelaskan besarnya persentase pengaruh variabel produksi perikanan laut sebagai variabel bebas terhadap kesejahteraan masyarakat sebagai variabel terikat dengan kofesien determinasi merupakan hasil dari $\mathrm{R}$. dari analisis diatas diperoleh koefesien determinasi (R2) sebesar 0,135 yaitu adanya Analisis produksi perikanan laut sebagai variabel bebas terhadap kesejahteraan masyarakat kabupaten Lamongan sebagai variabel terikat sebesar $13,5 \%$,sedangkan sisanya dipengaruhi variabel lain.

ANOVA $^{\mathrm{a}}$

\begin{tabular}{|l|r|r|r|r|r|}
\hline Model & $\begin{array}{c}\text { Sum of } \\
\text { Square } \\
\mathrm{s}\end{array}$ & $\mathrm{df}$ & $\begin{array}{c}\text { Mean } \\
\text { Squar } \\
\mathrm{e}\end{array}$ & $\mathrm{F}$ & Sig. \\
\hline $\begin{array}{l}\text { Reg } \\
\text { ression }\end{array}$ & .309 & 1 & .309 & .467 & $.544^{\mathrm{b}}$ \\
Residual & 1.987 & 3 & .662 & & \\
Total & 2.296 & 4 & & & \\
\hline
\end{tabular}

a. D Independent Variable: IPM

b. Predictors: (Constant),

Pertumbuhan Produksi Perikanan

Laut

Pada Tabel diatas menjelaskan adanya pengaruh yang nyata (Signifikan) produksi perikanan laut sebagai variabel bebas terhadap kesejahteraan 
kepada rakyat

miskin.Surabaya: Airlangga

University Press.

Csirke, J. 1988. Small Shoalding Fish Stock. In J.A Gulland, ed. Fish Population Dynamic, 2nd John Willy and Sons, Chechester

Dahuri, R. 2001.Menggali Potensi Kelautan danPerikanan dalam Rangka PemulihanEkonomi

Menuju Bangsa Indonesiayang Maju, Makmur dan Berkeadilan.Makalah pada acara temu akrab CivaFPi,tanggal 25 Agustus2001.Bogor.

Dahuri, R. 2002.Modul Sosialisasi dan Orientasi Penataan Ruang Pesisir dan PulauPulau Kecil. S.l. : Departemen Kelautan dan Perikanan. Jakarta.

Dinas Perikanan dan Kelautan Provinsi Jawa Timur. 2014. Statistik Perikanan Tangkap Provinsi Jawa Timur Tahun 2013.

Dinas Perikanan dan Kelautan Kabupaten Lamongan. 2013.Laporan Tahunan Bidang Perikanan Budidaya.

Direktorat Jenderal Perikanan Budidaya, 2012. Statistik Ekspor Hasil Perikanan tahun 2014. Departemen Kelautan dan Perikanan. Jakarta

Kelautan dan Perikanan Dalam Angka tahun 2015. Kementerian Kelautan dan Perikanan. Jakarta.

Keputusan Menteri Kelautan dan Perikanan Republik Indonesia Nomor Kep.

$\begin{array}{ll}\text { 18/Men/2011 } & \text { tentang } \\ \text { Pedoman } & \text { Umum } \\ \text { Minapolitan. } & \end{array}$

Kusnadi. 2006. Filosofi Pemberdayaan Masyarakat Pesisir. Bandung, Humaniora.

Lamongan Dalam Angka. 2015.

Lubis, Ernani. 2012. Pelabuhan Perikanan. Bogor. IPB Press.

Ma'ruf, W.F. \& Agus H.P. Perikanan Laut Melalui Penerapan UU 32/2004. Makalah Semiloka "Konsep PembangunanPerikanan dan Kelautan Propinsi Jawa Tengah dalam rangka Implementasi UU 32/2004".Semarang: $25-27$ Maret.

Murachman. 1987. Pengetahuan Hasil-hasil Perikanan. Fakultas Perikanan Universitas Brawijaya. Malang.

Pemerintah Kabupaten Lamongan. 2015. Gambaran Umum Kabupaten Lamongan.

Peraturan Bupati Lamongan Nomor 33 Tahun 2013 tentang Petunjuk Pelaksanaan Izin Usaha Perikanan di Kabupaten Lamongan.

Peraturan Daerah Kabupaten Lamongan Nomor 2 Tahun 2010 tentang Kepelabuhan di Kabupaten Lamongan.

Peraturan Daerah Kabupaten Lamongan Nomor 19 Tahun 2010 tentang 

Retribusi Tempat
Pelelangan.

Peraturan Daerah Kabupaten Lamongan Nomor 27

Tahun 2010 tentang

Retribusi Izin Usaha

Perikanan.

Peraturan Daerah Kabupaten Lamongan Nomor 15

Tahun 2011 tentang

Rencana Tata Ruang

Wilayah Kabupaten

Lamongan Tahun 20112031.

Sadly, H. 1980. Sosiologi untu masyarakat Indonesia. Jakarta: PT. Pembangunan.

Supriharyono. 2000. The Problem of Coastal And Marine Resources Management in Indonesia. Journal of Coastal Development Vol 4 No.1, October 2000 P: 41-49.

Sukmadinata,N.S. 2005. Metode Penelitian Penelitian. Cetakan ke 7. Bandung : Remaja Rosdakarya.

Sadly, H. 1980. Sosiologi untu masyarakat Indonesia. Jakarta: PT. Pembangunan. 